\title{
International human rights courts and the (international) rule of law: Part of the solution, part of the problem, or both?
}

\author{
A N D REAS F O L LES D A L \\ PluriCourts, Department of Public and International Law, University of Oslo
}

Email: andreas.follesdal@jus.uio.no

\begin{abstract}
Critics challenge international courts for their interference with domestic democratic processes and alleged violations of rule of law standards: they claim that these guardians of the rule of law are not well guarded themselves. These concerns should not be dismissed too quickly as mere disgruntled venting by populist politicians. This article focuses on regional human rights courts and argues that the same interests and values that justify rule of law standards of impartiality, independence and accountability domestically also justify similar standards for international courts. Focusing on the European Court of Human Rights and its doctrine of the margin of appreciation, the article demonstrates how this doctrine may contribute to fulfilling the rule of law but at the same time may also endanger it. This requires changes to the doctrine to ensure that the core rule of law standards of predictability and protection against arbitrary discretion are respected.
\end{abstract}

Keywords: European Court of Human Rights; human rights; international law; legitimacy; rule of law

\section{Introduction}

International courts, such as regional human rights courts (RHRCts), are often tasked to promote rule of law standards that we know from domestic settings. But RHRCts can also jeopardize those very standards and the values they protect. Critics argue, for example, that supranational judiciaries interfere with domestic democratic processes and rule of law standards. They allege that these guardians are not well guarded themselves.

What are we to make of such complaints? This article argues that we should not ignore possible conflicts between the practice of RHRCts and rule of law standards. These concerns should not be dismissed too quickly as mere protests by populist politicians. The unchecked independence of RHRCts can render them unpredictable and subject states and their citizens 
to an unconstrained, arbitrary and possibly biased discretion of these supranational courts. These are the very risks that rule of law standards are supposed to protect us against both domestically and internationally - or so this article argues. How, then, can we best guard the independent international guardians of the rule of law?

In order to answer this question, we need to reconsider the nature of the rule of law and ask which rule of law standards and values apply (also) to international courts. The article first restates in section II some of the dominant conceptions of the rule of law. Judging from the extent of contestation, 'the rule of law' appears to be an exceedingly elusive, perhaps even 'essentially contested', concept (Gallie 1955-56: 169; Tamanaha 2004; Traisbach (in this issue); Waldron 1989).

Regarding the international rule of law, disagreements escalate even further. Some critics doubt the very existence and desirability of such principles on the supranational level. Others do not go that far, but do question the relation between international and domestic standards (Chimni 2012; Kumm 2003-04, 2009; Waldron 2006, 2011). Section III seeks to provide some unity and consistency between the domestic and international versions of the rule of law by taking one philosophical step back before moving forward. A first step is to identify the interests of individuals that give us reason to value domestic rule of law standards before we can ask whether and how these standards can be applied in the international context. Two central interests are at stake, which are related but not identical: to enhance predictability of others' conduct; and to promote 'non-domination' by reducing the risk of being subjected to arbitrary discretion by governments and other authorities.

These interests have implications also for the institutions that develop and adjudicate international law and protect rule of law standards, including RHRCts. They may help to increase predictability and prevent domination. But these judicial bodies may also contribute to causing these problems, so they should be subject to similar rule of law standards of impartiality, independence, predictability and legality to domestic judiciaries.

Two features of RHRCts create particular challenges in light of the various rule of law standards, and particularly the two values of nondomination and predictability. First, since RHRCts often adjudicate disputes involving states, they must be sufficiently independent from states in order to adjudicate impartially. Second, international courts function outside the well-developed accountability mechanisms of checks and balances that we find in some domestic constitutional orders. For instance, domestic legislatures can correct what they regard as a misguided interpretation of the law by a domestic court by revising the relevant legislation. In contrast, the avenues for holding international courts accountable and for 'correcting' 
their jurisprudence are more piecemeal and fragmented. The combination of these two factors understandably fuels fears that RHRCts exercise too much unchecked discretion. They may therefore become new sources of domination when they carry out their mandate because their jurisprudence affects domestic human rights and the domestic rule of law.

Against this background, the article discusses both aspects in more detail: how the European Court of Human Rights (ECtHR, or the Court) promotes the domestic rule of law in member states (section IV) and how it can endanger the rule of law (section V) before suggesting avenues via which the Court may mitigate the potential dangers. Section IV considers a prime example of how the ECtHR can avoid domination and unpredictability by showing deference toward state parties. The doctrine of a 'margin of appreciation' arguably promotes human rights and the rule of law without imposing new risks to those standards. This doctrine arguably allows the ECtHR to oversee states' compliance with their human rights obligations, albeit at arm's length. It even strengthens the domestic rule of law while expressing appropriate deference to the state.

Section V challenges this claim and argues that the doctrine of a margin of appreciation, as currently developed by the ECtHR, does not avoid the dilemma. To the contrary, the doctrine creates new risks of arbitrary discretion, contrary to the rule of law values the Court is tasked to guard. The critics' concerns can thus not be ignored and should spur changes to the doctrine of a margin of appreciation to better satisfy the rule of law standards and values. Further developments of the doctrine should reduce the ECtHR's discretion and the unpredictability in its application in order to prevent this guardian of the rule of law and human rights from becoming an unpredictable source of domination.

\section{Conflicting conceptions of the rule of law: Domestic and international}

Discussions about the rule of law in domestic settings typically include several principles or values. Dicey's canonical list specifies three principles: (1) Supremacy of regular law over arbitrary power; (2) equality before the law, even for government officials; and (3) constitutional law as a binding part of the ordinary law of the land (Dicey 1959: 198-99). Fuller's (1964) more expansive eight desiderata of the 'inner morality of law' include general applicability, promulgation, non-retroactivity, clarity, consistency (within human capability), stare decisis, possibility of obedience and congruence between meaning and application. Raz (2019; cf Raz 1979, 217-18) lists eleven principles: laws should be reasonably clear; reasonably stable; publicly available; consist of general rules and standards; which are 
applied prospectively and not retroactively; governmental decisions should be supported by publicly declared reasons; should result from a fair and unbiased process; which is adequately open and participatory; the decisions should be reasonable, relative to their declared reasons; officials (including judges) should conform to (local) conventions of how to conduct legal business, including that their actions serve the interests of the governed; and finally, the doctrine of the rule of law and what it implies should be an obvious and vital part of public culture. Tamanaha $(2004,2012)$ identifies three main themes of rule of law standards: (1) government limited by law; (2) formal legality; and (3) 'the rule of law, not man'.

In addition to such various 'thin' notions of the rule of law, several lists include further substantive conditions, including some set of human rights, democratic rule or the protection of certain minimum social or economic conditions. Thus the Committee on the Legislative and the Law of the International Congress of Jurists held in 1959 that the rule of law requires 'not only the recognition of his [i.e. of man] civil and political rights but also the establishment of the social, economic, educational and cultural conditions which are essential to the full development of his personality' (see also Raz 1979: 210-11).

For the international rule of law, there is an even broader range of reasoned alternatives. Kumm (2003-04: 22) claims that, at least for some issues, 'The international rule of law is realized to the extent states do in fact obey international law.' Crawford (2014: 342-43) proposes a broad list:

first, that no one is outside the law, still less above it; second, that it is by some means or in some sense democratic, at least in the sense of being accountable to others; third, that its instituted authorities - notably the Security Council - are in principle subject to legal constraint; fourth, that there is something like a constitution of international society; and fifth, that society is not irremediably unjust.

Given this plethora of alternatives, how might we best determine the appropriate standards of the international rule of law - standards that are appropriate for RHRCts? We need to ensure some consistency between domestic and international rule of law standards while acknowledging their different subjects and circumstances (Ulfstein 2018).

One proposed strategy for 'extending' domestic rule of law principles to international law is by analogy between individuals and states. Just as the freedom of individuals must be protected against the power of their governments by means of the rule of law domestically, so must the freedom of states be protected by the same rule of law norms at the international level. The UN General Assembly might be understood to maintain this view when claiming that the international rule of law is 'the rule of law among nations' 
(UN General Assembly 1970). Several authors point out that such arguments by analogy arguably fail on several crucial points, three of which merit particular mention. First, the values protected domestically by rule of law standards are the interests of individuals rather than states. Second, among the interests of individuals protected by the rule of law, many hold that liberty is central in some sense. Yet individual liberty and the sovereign freedom of states are fundamentally different. Third, the risks against which rule of law standards protect relate to the abuse of centralized state power (Hurd 2015; Waldron 2011). Neither of these domestic values transposes easily to the interests of states in the current international legal order:

[Thus] the most morally compelling features of the ideal of the rule of law have to do with the ways in which a legal system can protect individuals' interests and respect individuals' autonomy; but much of IL concerns the relations among states and in many cases states do not represent the interests of some or even most of their citizens. So it is not clear just how the commitment to the rule of law is to be cashed out in the international arena. (Buchanan 2006: 314-15, quoted by Waldron 2011: 323).

So we cannot simply assume that the principal justification of international rule of law standards is to protect states' freedom against some centralized authority. A possible alternative for this analogical reasoning is to explore some of the foundations of rule of law standards. Thus we can ask which foundational values the rule of law protects domestically and what implications follow from these for international law and international actors such as RHRCts.

\section{Extrapolating the rule of law: From the domestic to international settings}

Instead of relying on flawed analogies, we follow a strategy that Krygier (2008) also recommends: starting with the ends of the rule of law, rather than what purports to be its institutional anatomy. The first step is to identify which interests of individuals domestic rule of law standards protect and promote. We then ask in a second step which norms, institutions and practices can help international courts secure those same interests of individuals who are organized in states on the international plane, a setting that carries other opportunities and risks. The range of individuals' interests that justify the claim that their state should comply with domestic rule of law standards may also support international standards and institutions that seek to guide and constrain states so that they indeed act as their citizens' trustees and agents. 
Which interests underlie domestic rule of law standards? We may answer this question through careful inductive conjecture by checking competing proposed interests against various proposed standards. At least three justificatory accounts may be discerned that reflect the distinct interests of individuals.

Rule of law standards may be understood in the broad sense of just rule as, for example, the aforementioned International Congress of Jurists proposed in 1959. This may subsume human rights and democratic rule. Second, rule of law standards provide more predictability about the law, and hence about actions of public authorities. Thirdly, they consequently reduce the risk of individuals of being subjected to the arbitrary discretion of agents - an interest in non-domination. These three rationales are distinct but clearly support somewhat overlapping sets of rule of law standards both for domestic and international settings. I shall argue in accordance with several other scholars that the two interests in predictability and nondomination lie at the foundation of a familiar cluster of rule of law norms.

What are we to make of the first proposed interest: that the rule of law serves to protect and promote a broad substantive conception of just rule, including human rights and democratic governance? Bingham (2010: 67, cited in Waldron 2016), for example, favours 'a "thick" definition, embracing the protection of human rights within its scope. A state which savagely represses or persecutes sections of its people cannot ... be regarded as observing the rule of law.'

On the other hand, many scholars and authorities distinguish the rule of law and human rights. For instance, the objectives of the Venice Commission of the Council of Europe include 'spreading the fundamental values of the rule of law, human rights and democracy' (Committee of Ministers of the Council of Europe 2002). Some may be wary of introducing any substantive values as rule of law standards, fearing contestation about which values to include. This is not a convincing argument in this context since what we seek are substantive values in support of varying sets of rule of law standards. The aim is not to avoid value-laden premises altogether (Pavel 2019: 8). Rather, we exclude other normative standards from the definition of the rule of law based on our critical analysis of dilemmas with no intention of dismissing or silencing such important normative questions. One implication is that rule of law standards are only one of several sets of values that legal orders need to secure in order to be legitimate. Thus, on this account, authorities can increase compliance with their rules by respecting the rule of law (Hurd 2015: 367; Waldron 2011: 337). Yet this claim may be unfounded. We should not assume that improvements of rule of law standards render a society more just, more independent of the normative quality of the legal 
regime in place. ${ }^{1}$ Autocracies may still be deeply illegitimate despite complying with rule of law norms.

Consider, then, the second account. Several scholars appear to defend a justification of rule of law norms based on individuals' interest in predictability. For instance, $\operatorname{Raz}$ (1979: 214; cf Waldron 2011: 338) maintains that 'the basic intuition from which the doctrine of the rule of law derives [is that]: the law must be capable of guiding the behaviour of its subjects'. This seems plausible. In addition, I submit that, apart from this interest, some rule of law standards are better accounted for on the basis of an interest in non-domination.

The third account maintains that protection against arbitrary rule is a further, separable value, different from predictability (Raz 1979: 219). For the individual, there is value in a particular kind of liberty: the protection from arbitrary political authority that is not controlled by the affected subjects - 'non-domination' in short (Pettit 1997, 2010). For our purposes, the central point is that rule of law standards contribute not only to enhanced predictability, but to protection against and guidance of the discretion of powerful authorities. Protection against such domination has been a central value in much Western political thought (Pettit 1997, 2010; Skinner 1998). Such objectionable domination may occur even when the authorities do not exercise their discretion (Pettit 2009: 44). And it is not limited to domestic authorities: citizens and their 'representative states may be subject to the dominating control of public, international bodies' (Pettit 2015: 55).

Why should this interest also be part of rule of law standards? For many observers, one reason is that even completely predictable discretion by authorities over their subjects is objectionable. Moreover, several authors appear to appeal to this interest when they claim that this particular form of disappointed expectations in the stability of law is especially objectionable and even disrespectful: 'When such frustration is the result of human action or the result of the activities of social institutions then it expresses disrespect' ( $R a z$ 1979: 222). A combination of the interests in predictability and nondomination also appears to fit better with Tamanaha's (2004) historically informed list. The norms securing formal legality and avoiding 'unpredictable predilections of individual actors' (2004: 497) may indeed be justified partly by concerns about predictability. But he also notes such norms as restraints on the law-making power of governments in order to avoid government tyranny (2004: 497) which appears to fit better with the concern for non-domination. Chimni (2012) likewise holds that its essence is the

${ }^{1}$ Pace Waldron (1989: 31): 'the lead idea of the Rule of Law is that somehow respect for law can take the edge of human political power, making it less objectionable, less dangerous, more benign and more respectful'. 
prohibition of the exercise of arbitrary power and Martin Krygier (2008) argues that a central end of the rule of law is to reduce arbitrariness.

I conclude that most, if not all, domestic rule of law standards can be justified as means to protect and promote one or both of two central interests of individuals at the domestic level: non-domination, understood as protection against the arbitrary will of others; and predictability, understood as being able to predict the actions of others.

Some further elaboration of these interests in non-domination and predictability is required in order to understand the implications for the international rule of law and for international courts in particular. The interest in nondomination arguably justifies a variety of rule of law standards that help control the exercise of discretion and protect against arbitrary decisions. There exist important variations in terms of how to specify 'arbitrary' in this context (cf Blunt 2015). For our purposes, this account is helpful:

When we say that an act of interference is perpetrated on an arbitrary basis ... we imply that it is chosen or rejected without reference to the interests, or the opinions, of those affected. The choice is not forced to track what the interests of those others require according to their own judgements. (Pettit 1997: 55).

Protection against arbitrariness of this kind is important domestically against rulers and governments - which is largely Waldron's focus when discussing the international rule of law (Waldron 2011:323). Note that this interest in non-arbitrariness and non-domination is more limited than a general interest in securing the individual's autonomous choice from among a broad domain of alternatives. The latter might arguably express a more individualistic and Western value. Tamanaha's distinction seems appropriate here: the focus is 'not on individual liberty, but on restraint of government tyranny ... It means first that government officials must abide by the currently valid positive law, and second there are restraints on their lawmaking power' (Tamanaha 2004: 497-98).

This includes requirements of legality to ensure that authority is exercised only within certain domains and according to certain procedures and legal norms. Various institutional checks and balances help reduce the risk that authorities exceed their mandate by guiding or restricting the use of their powers. This interest similarly justifies a principle of non-retroactivity and welcomes impartial, peaceful, rule-guided dispute resolution. In addition, the interest also grounds claims of individuals to be protected by the state or other authorities against the arbitrary discretion of powerful private actors. All of this is important in order to reduce the risk of domination among private actors as well as by state authorities, including courts. Several rule of law norms are required if individuals are to trust the judicial function of non- 
arbitrary and unbiased dispute resolution. These interests are expressed in standards of impartiality and independence (Crawford and McIntyre 2012: 190).

Our interest in predictability, on the other hand, is due to our need to make long-term plans in pursuit of our various interests with some expectation of success. This need for coordination and planning explains our interest in being able to rely on others' compliance with legal rules and in particular not to fall victim to unexpected actions by the government (Raz 1979). Martin Krygier (2008: 58) elaborates this value in complex large societies:

The rule of law can provide fellow citizens with crucial information and security, 'a basis for legitimate expectations', by enabling them to know a good deal about each other, although many of them are strangers; to co-ordinate their actions with each other; and to feel some security and predictability in their dealings with each other. For although not everything can ever be made predictable, much that would otherwise be up for grabs can be tied down.

This interest in stable, legitimate expectations lends further justification to many familiar standards of legality and, in the context of courts, to practices of precedents in order to enable citizens to coordinate in light of past judicial decisions.

We now turn to whether and how these interests in non-domination and predictability are also reflected in international rule of law standards and implications of this for RHRCts in particular. Note that this specific topic is not quite as starkly different from the domestic relationship between individuals and courts as many other questions related to the international rule of law. We are not primarily concerned here with the relationship between states on the international level, but rather with the relationship between individuals and state authority - outside the main concerns of Hurd (2015: 368) and Waldron (2011: 322-23).

The main tasks of RHRCts largely correspond to those of domestic courts: to provide impartial dispute resolution on the basis of legal norms and by applying judicial methods, including the identification and development of the relevant law. This also bears risks that domestic and supranational courts share. We have seen already that the danger of dominance is one reason why several scholars are concerned about domestic judicial review in general (Bellamy 2007; Tamanaha (in this issue); Waldron 2006 (in this issue)). Some of the risks these scholars highlight appear to be even greater for international courts, since it is more difficult to subject them to control by states and their legislatures.

One could argue, however, that the possible risks that RHRCts pose are somewhat alleviated insofar as these courts mainly serve as a subsidiary 
mechanism to strengthen and correct the domestic judiciary. Failures of RHRCts would thus seem less of a threat to the interests of individuals and their states.

If a RHRCt mistakenly fails to rule against a state, the individual is not much worse off in terms of predictability and non-domination regarding domestic authority than if the RHRCt did not exist at all. If, on the other hand, a RHRC mistakenly rules against a state, the state may be required to provide unnecessary compensation or adjust policies and legislation unnecessarily, but the state can avoid such costs - at least in the long run - by withdrawing from the regional human rights treaty (Hurd 2015: 378).

Yet these arguments are not convincing. The first argument contradicts the very purpose of RHRCts to correct domestic shortcomings. An erroneous decision of a RHRCt clearly affects interests of the individual negatively. The second argument misunderstands that the possibility to withdraw is often politically or legally unavailable. Consider, for example, that membership in the Council of Europe, including ratification of the European Convention on Human Rights (ECHR), is a de facto requirement for membership of the European Union. Hence, although mistakes by RHRCts are not necessarily as harmful to particular individuals as miscarriages of domestic justice, they do incur costs for individuals and their states.

The rule of law norms that serve to secure non-domination and predictability should hence also apply to international judiciaries. This line of argument inter alia lends support to the Burgh House principles for the impartiality and independence of the international judiciary (International Law Association Study Group 2004, reprinted in Sands, Mackenzie and McLachlan 2005: 251-60; cf Crawford and McIntyre 2012).

\section{The ECtHR as part of the solution: Promoting the rule of law rather than arbitrary rule}

We first consider how RHRCts - and the ECtHR in particular - may promote the rule of law within states before analysing the counter position in the next section. RHRCts may help enhance predictability and protect individuals against domination from domestic, international and transnational actors. Most evidently, they do this through monitoring compliance, interpreting applicable norms, adjudicating disputes and triggering local responses to human rights violations. They thus help states to fulfil their treaty obligations, increase the predictability of their actions and reduce the risk of arbitrary decision-making.

One means by which the ECtHR in particular promotes domestic rule of law standards and the values of predictability and non-domination merits 
closer scrutiny: the doctrine of a 'margin of appreciation'. In some circumstances, the ECtHR will refrain from an independent detailed review of whether a state is in compliance with its treaty obligations. Instead, it may defer the assessment of state measures completely to domestic authorities, or it may subject the measures to less strict scrutiny. The Court thus grants the accused state a certain margin of discretion.

The Court has used such a margin in at least three areas. The first is 'balancing' Convention rights against other urgent issues such as emergencies, public safety or the economic well-being of the country, especially in the context of the rights to private life, religion and freedom of expression (Articles 8, 9, 10). The second issue area concerns the 'balancing' or certain 'tradeoffs' among Convention rights, such as between freedom of expression (Article 10) and privacy (Article 8). Third, a state may be accorded a margin of appreciation for some challenging applications of the Convention norms to the specific circumstances of a society - for instance, when the majority's moral views or other values are challenged.

Many see the margin of appreciation doctrine as a way for the ECtHR to 'balance the sovereignty of Contracting Parties with their obligations under the Convention' (Macdonald 1993: 123), enabling the Court to pay due respect to both the ECHR and to its sovereign creators. A further aspect of the margin of appreciation doctrine which may be seen as an expression of deference toward trends among state parties is that the Court is less likely to grant a (wider) margin in matters where the Court sees an emerging European consensus among the state parties (Wingrove $v$ United Kingdom 1996; X, Y and Z v United Kingdom 1997; Dzehtsiarou 2015). In these cases, the Court appears to restrain its deference to a particular state by deferring instead to the (emerging) consensus among all state parties.

One of several conditions for the Court to grant a margin of appreciation is often that state authorities have performed a 'proportionality test' (Handyside $v$ United Kingdom 1976). The state must have considered whether the measure was proportionate to the pursued aim or whether the same social objective could have been achieved by other, less restrictive measures. That is, the domestic judiciary must have reviewed whether the alleged infringement of the Convention is 'proportionate' to the objectives pursued by the state, and whether these objectives themselves are permitted under the ECHR. Note that there are exceptions to this rule (Schalk and Kopf v Austria 2010) and that such a proportionality test is, of course, not a sufficient condition for a state to enjoy a margin of appreciation: even when the Court finds that such a domestic proportionality test has been carried out satisfactorily, it may still not grant a margin of appreciation. In several cases, however, the Court appears to have explicitly regarded evidence that the state has actually carried out a proportionality test as a necessary condition for the Court to grant a 
margin of appreciation (Hirst $v$ United Kingdom (no 2) 2005; Animal Defenders International $v$ United Kingdom 2013).

I submit that this requirement of a visible proportionality test may help promote rule of law standards and the value of non-domination in particular. This test helps to ensure not only that states honour their legal obligations, but that they also show they have considered and assessed alternative measures or policies in light of their impact on individuals' rights and the permissible objectives sought. This requirement reduces the risks of arbitrary, unconstrained discretion by domestic authorities. By insisting on such evidence as a necessary (though insufficient) condition for granting a margin of appreciation, the Court arguably gives states an incentive to comply with rule of law standards and reduce their discretion. Thus the ECtHR serves a further valuable 'prescriptive' or 'positive' subsidiary role regarding rule of law standards (Follesdal 1998): it not only reviews whether domestic authorities violate human rights, but the margin of appreciation doctrine helps strengthen the independent domestic judiciary and domestic compliance with international obligations.

A further optimistic defence of this requirement is that it alleviates a flaw in those attempts at rule of law promotion that only target legal and institutional aspects. Such checks and constraints have a stronger societal impact if they are part of a culture that uses the laws to actually effectively constrain the powerful. Thus Krygier (2008: 60) argues that 'the institutionalised norms need to count as a source of restraint and a normative resource, usable and with some routine confidence used in social life'. Arguably, the ECtHR serves a further 'positive' subsidiary role when it helps to foster such a law-abiding culture by nudging domestic legislatures, executives and judiciaries to regularly consider how their plans will affect individuals' human rights - and how alternatives could minimize detrimental impacts. To foster such a mindset, it arguably helps to ensure that

law might be said to rule ... when the law counts significantly, distinct and even in competition with other sources of influence, in the thoughts and behaviour, the normative economy, of significant sectors of a society. (Krygier 2008: 65)

\section{ECtHR as part of the problem: How guard the guardians of the rule of law?}

What are the implications of this account of rule of law standards and values regarding the margin of appreciation doctrine of the ECtHR? Even though many rule of law standards are contested - especially for international bodies - many authors agree on the need for an independent and impartial 
judiciary both at the domestic and international level. Rule of law standards are necessary for courts to perform their central task of unbiased dispute resolution based on legal norms and judicial methods. Courts must be impartial if they do not want to become tools for domination by one party.

Independence is also important to enhance predictability concerning these matters among the parties. This is especially important for international courts that usually only hear cases to which the parties have consented. Yet the importance of rule of law standards for the ECtHR is not primarily about the need for predictability. If predictability were the prime concern, this might lead to policies of minimal intrusion by the ECtHR into state actions. That would fundamentally misconstrue the tasks of human rights courts. Rule of law standards need to foster both predictability and non-domination for citizens of democratic states - against their own state but also against other bodies, including international courts.

From whom a court should be independent, among whom they should be impartial, and how this should be ensured, depends on the disputes it adjudicates. In the domestic setting, independence from the executive and the legislative branch as well as from the parties is important if the task of a court is to restrain state power and to ensure that nobody is judge in their own case.

There are several risks of domination wrought by an international court. In the context of the ECtHR, I submit that the margin of appreciation doctrine as currently developed by the ECtHR illustrates challenges in the institutional design of international bodies - courts in particular: how to create both an independent and accountable ECtHR; how to guard the guardian of the rule of law? (Waldron 2002: 147-48); how to reduce the likelihood and possible damage wrought by judges who are able to issue judgements at their discretion (Follesdal 2014); what standards and guidelines can guide judges to base their decisions on judicial method.

In democratic domestic settings, this is achieved by making courts and the laws they adjudicate indirectly accountable to the populations they serve. International courts have other risks of bias and other modes of control. There exist several possible sources of bias and misuse of discretion by international judges: their legal ideology, personal quirks, corruption, being puppets of a state party, and risks of institutional entrepreneurs (Follesdal 2017). Judges must be experts in the relevant law, but they may still face situations where there is disagreement about legal interpretation, and therefore room for their personal ideology. In these cases, there is a risk that the judge brings her own idiosyncratic theory to bear to such an extent that it violates standards of good judging. A second risk is that international judges may pursue their own personal preferences or prejudices - ranging from discriminatory attitudes towards some segment of a population, to a distaste 
or preference for certain economic policies (Waldron in this issue). A third risk is that judges can become corrupt for their private gain. Fourth, judges may serve as puppets - as pawns or marionettes - for powerful states that nominate them (Shapiro 1981: 1-64; Voeten 2013). Thus former Belgian ECtHR judge Françoise Tulkens observed that, 'The raison d'etat is more present here than I would have thought possible' (Bruinsma 2006; see also Voeten 2008). There exist also reports about individual judges who are insufficiently independent from the nominating state or otherwise unsuitable for office (Engel 2012; Kosar 2015). Fifth, there is an 'entrepreneurial' risk. Judges, particularly on a new international court, must build the court's legitimacy 'capital' and authority among various compliance constituencies (Alter 2014). The risk of abuse of discretion arises when judges or administrative bodies of an international court want to increase the power of the institution by making judgments at odds with what standards of legality and the objectives of the founding treaty require.

Turning to the question of how the procedures and practices of the ECtHR address these risks in their institutional environment, let us first consider the good news before identifying some remaining challenges caused by the margin of appreciation doctrine. Several mechanisms exist to check or guide the discretion of judges. They include accountability structures concerning how judges are appointed, and ways to guard and guide the international court as a whole. The objective is to hold the court to professional legal norms of reasoning during the process and in its judgments in order to ensure that the decisions are sound and regarded as authoritative.

The design challenge for such mechanisms is complex, since the checks and accountability structures must allow the international court to be sufficiently independent of the states it monitors. The ECtHR seeks to combine accountability and independence by a procedure whereby each state party is represented by one judge for a non-renewable nine-year term. Each state nominates three candidates through a 'fair transparent and consistent national selection procedure' (Council of Europe Parliamentary Assembly 2009), from whom the Parliamentary Assembly of the Council of Europe selects one. The Assembly is guided by advisory panels of experts established by the Council of Ministers in 2010, and the Committee of Ministers' Guideline on Selection of Candidates, agreed in 2012.

This process generally seems to reduce the risks mentioned. There appears to be little bias among judges of the ECtHR towards their home states, some instances notwithstanding. Erik Voeten (2008) finds no evidence in support of any such general trends in the actual judgments (cf Kuijer 1997, cited in Kosar 2015). Nor are the judges of the ECtHR more likely to vote for countries on which their national governments depend - for example, 
for trade. Voeten ( 2008: 429-30) finds only a weak but no statistically significant positive correlation.

This lack of bias may partly be due to the nature of the ECtHR compared with other international courts: the ECHR is a treaty whereby the state commits itself to respect human rights norms in relation to its own actions. These complaints are usually lodged by individuals, while interstate complaints are extremely rare in the ECtHR. The ECtHR is mainly a mechanism to bolster the domestic rule of law protection of citizens against abuse of discretion by their own states. This is important for many states in order to enhance their credibility in the eyes of their own citizens - and sometimes in the eyes of other states. Thus membership of the European Union requires states to subject themselves to the ECtHR, partly so other states can trust that only human rights-respecting governments participate in the shared rule. In contrast, many other international courts help states to address collective action problems - for example, in international trade. These international courts and tribunals facilitate states making more credible commitments in the eyes of other states and private actors with regard to possible future disputes concerning trade agreements. In such 'otherbinding' international courts (Alter 2008), judges may be expected to exhibit more of a bias towards their own state.

Against this background, we now turn to consider some weaknesses of the margin of appreciation doctrine in securing the ECtHR's respect for rule of law standards and values. It can arguably serve as a much-needed accountability tool for the Court, but still has some weaknesses. There are several parts of the doctrine that leave too much space for arbitrary discretion by the judges.

First, the identification of a 'European consensus' plays a central role in the ECtHR's margin of appreciation doctrine, which arguably reduces the risk that the Court will abuse its review power. The ECtHR constrains its discretion insofar as it aligns its own judgments to sightings of a European consensus concerning democratic developments within its member states. The (emerging) European consensus guides and constrains the Court's interpretation of the Convention and its decision to grant a discretionary margin to states. However, some scholars regard this as 'majoritarian activism':

[The ECtHR] raises the standard of protection in a given domain when a sufficient number of states have withdrawn public interest justifications for restricting the right. Put differently, the margin of appreciation shrinks as consensus on higher standards emerges. The move will always put some states out of compliance. Yet the court and its supporters can claim that majoritarian activism constitutes an external, 'objective' means of 
determining the weights to be given to the legal interests in tension, leaving the losing state to defend a lower standard of rights protection on seemingly idiosyncratic grounds. (Stone Sweet and Brunell 2013: 78-79)

Although the grounding of a decision in a European consensus provides some accountability criteria for decisions of the ECtHR, this remains a weak accountability mechanism in several ways. The ECtHR is not forced to track what the states agree to. Critics also claim that the ECtHR detects such an emerging consensus in a haphazard way (Benvenisti 1999; Letsas 2007). To strengthen its guiding role and reduce the risk of domination, the ECtHR should develop the doctrine with clearer criteria for identifying a 'consensus'. This includes, for example, whether such a consensus needs to be expressed by legislatures or judiciaries, and whether it needs to be explicit or tacit.

A second related concern is that the doctrine is too vague in general and leaves too much discretion to the judges. In effect, the doctrine itself can become a tool for domination by the Court. Critics claim that the vagueness of the doctrine allows that the decision about whether or not a state is found to be in violation of the ECHR is a matter of arbitrary discretion (Benvenisti 1999: 844; Kratochvil 2011). Others warn that the doctrine allows the ECtHR to avoid damaging conflicts with powerful states which violates rule of law standards of treating like cases alike (Macdonald 1993). Note that the problem of domination arises not only when an authority actually abuses its discretion, but simply when its discretion allows it to do so. Thus, the actual incidence rate of improper use of discretion is not central to this argument.

Several valuable contributions lay out different components of the doctrine (e.g. Brems 1996), but many observers call for more clarity (Gerards 2011), including for instance whether a domestic good faith public proportionality test should be required before the ECtHR grants any such margin. The upshot of this reflection is that the margin of appreciation doctrine, as currently developed by the ECtHR, can make the Court into a source of domination.

However, these criticisms of the margin of appreciation doctrine are not insurmountable. As mentioned before, the ECtHR should lay out more carefully the conditions under which it will grant a margin: which rights need to be at stake, which societal objectives, how detailed the proportionality test must be, and what else needs the state to show to secure such a margin. Insofar as such criteria are public and defensible, they could reduce the risk (and the suspicion) that the Court uses its discretion arbitrarily.

As an example, consider again the particular proportionality test the Court applies. There are arguably other ways to test whether a state has 
attended appropriately to the rights of affected parties. The Hirst case concerning the United Kingdom's decision regarding prisoners' voting may illustrate this. The UK Parliament debated and decided the issue, but not in the way the ECtHR found necessary, and hence the Court did not grant the United Kingdom a margin of appreciation. Criticisms against the Court concerning this case have been rampant. It would seem that one important step to reduce criticism of undue interference with wellfunctioning domestic democratic procedures would be to make the steps of the Court's proportionality test more explicit, and to defend this test as preferable to alternative modes of public deliberation that seek to balance conflicts between the Convention and particular policy proposals.

Are such developments toward a more precise margin of appreciation doctrine likely? Protocol 15, which has yet to enter into force, will include explicit reference to the margin of appreciation in the Preamble of the Convention (Council of Europe 2013). We may hope that this inclusion will further strengthen the calls for a more precise and justifiable doctrine. The margin of appreciation doctrine may thus serve as a mechanism to further the interests that justify rule of law standards generally: it may nudge states toward more regulated discretion concerning proportionality considerations and reduce the ECtHR's own discretion in granting a margin of appreciation.

\section{Conclusion}

International human rights courts are created to bolster the domestic rule of law and democracy in signatory states. Critics have questioned whether, paradoxically, these guardians of the domestic rule of law may themselves threaten those very same standards. Even though such criticism may be exaggerated and ultimately can be refuted, it should not be dismissed easily. The case of the ECtHR is an apt example of the risk of arbitrary discretion of RHRCts. Yet the conceptual and practical defences against the critique need refinement.

Some rule of law standards are relevant for international bodies as well. The present reflections explicated some rule of law standards applicable to international bodies, with special attention to regional human rights courts such as the ECtHR. We first considered which interests of individuals are protected and promoted by domestic rule of law standards . Arguably, these values include preventing domination - in the form of arbitrary discretion and enhancing predictability. The ECtHR can indeed promote these rule of law standards and values by reviewing states' compliance with the ECHR and by controlling the discretion of state authorities so they engage carefully 
in the requisite balancing of convention rights against other important objectives.

However, like other international bodies, the ECtHR faces peculiar rule of law dilemmas: it needs to secure its independence from member states and at the same time be sufficiently accountable to these masters of the treaty. The ECtHR's margin of appreciation doctrine is Janus-faced in this regard. On the one hand, it may promote the domestic rule of law and reduce the risk of the ECtHR itself becoming a source of domination. Yet the doctrine is currently so vague that the Court often stands accused of exercising too much arbitrary discretion, which violates rule of law standards of independence and impartiality.

There are other values and standards beyond those of the rule of law that a legitimate international political and legal order should protect, and some rule of law standards remain contested. Yet the argument pursued here suggests that even the international guardians of domestic rule of law must live up to at least some of the very same standards that they guard. We should welcome and support the efforts of regional human rights courts to guide and constrain their own discretion in light of the standards and values of the rule of law.

\section{Acknowledgements}

This article was written under the auspices of ERC Advanced Grant 269841 MultiRights - on the Legitimacy of Multi-Level Human Rights Judiciary; and partly supported by the Research Council of Norway through its Centres of Excellence Funding Scheme, project number 223274 - PluriCourts, The Legitimacy of the International Judiciary. An early first version of the argument was presented at the Venice Academy of Human Rights 2014. I am very grateful for comments received there and afterwards, especially from Knut Traisbach and Geir Ulfstein and from the Journal's anonymous reviewers.

\section{References}

\section{Cases}

Animal Defenders International v United Kingdom. 22April 2013. ECtHR App No 48876/08. Handyside $v$ United Kingdom. December 7, 1976. ECtHR App No 5493/72.

Hirst $v$ United Kingdom (No 2). 6 October 2005. ECtHR App No 74025/01.

Leyla Sahin v Turkey. 29 June 2004. ECtHR App No 44774/98.

Schalk and Kopf $v$ Austria. 24 June 2010. ECtHR App No 30141/04.

Wingrove $v$ United Kingdom. November 25, 1996. ECtHR App No 17419/90.

$X, Y$ and $Z v$ United Kingdom. April 22, 1997. ECtHR App No $21830 / 931997$. 


\section{Legislation}

Committee of Ministers of the Council of Europe. 2002. Revised Statute of the European Commission for Democracy through Law (the Venice Commission), Res(2002)3. 21 February 2002.

Council of Europe Parliamentary Assembly. 2009. Nomination of candidates and Election of Judges to the European Court of Human Rights. Resolution 1646. 27 January 2009.

Council of Europe. 2013. Protocol No. 15 Amending the Convention on the Protection of Human Rights and Fundamental Freedoms. Council of Europe Treaty Series No 213. 24 June 2013.

International Law Association Study Group. 2004. The Burgh House Principles on the Independence of the International Judiciary.

UN General Assembly. 1970. Declaration on Principles of international Law Concerning Friendly Relations and Co-operation Among States in Accordance with the Charter of the United Nations. A/RES/25/2625. 24 October 1970.

\section{Secondary sources}

Alter, Karen. 2008. 'Delegating to International Courts: Self-binding vs. Other-binding Delegation'. Law and Contemporary Problems 71(1):37-76.

Alter, Karen. 2014. The New Terrain of International Law: Courts, Politics, Rights. Princeton, NJ: Princeton University Press.

Bellamy, Richard. 2007. Political Constitutionalism: A Republican Defence of the Constitutionality of Democracy. Cambridge: Cambridge University Press.

Benvenisti, Eyal. 1999. "Margin of Appreciation, Consensus, and Universal Standards". New York University Journal of International Law and Politics 31(4):843-54.

Bingham, Tom. 2010. The Rule of Law. London: Allen Lane.

Blunt, Gwilym David. 2015. 'On the Source, Site and Modes of Domination'. Journal of Political Power 8(1): 5-20.

Brems, Eva. 1996. 'The Margin of Appreciation Doctrine in the Case-law of the European Court of Human Rights'. Heidelberg Journal of International Law 56:240-314.

Bruinsma, Fred J. 2006. 'Judicial Identities in the European Court of Human Rights'. In Multilevel Governance in Enforcement and Adjudication, edited by Aukje van Hoek, Antoine Hol, Oswald Jansen, Peter Rijpkema and Rob Widdershoven, 203-40. Antwerp: Intersentia.

Buchanan, Allen. 2006. 'Democracy and the Commitment to International Law'. Georgia Journal of International and Comparative Law 34(2):305-32.

Chimni, Bhupinder S. 2012. 'Legitimating the International Rule of Law'. In The Cambridge Companion to International Law, edited by James Crawford and Martti Koskenniemi, 290-308. Cambridge: Cambridge University Press.

Crawford, James. 2014. Chance, Order, Change: The Course of International Law, General Course on Public International Law. Leiden: Brill.

Crawford, James and McIntyre, Joe. 2012. 'The Independence and Impartiality of the "International Judiciary"'. In The Culture of Judicial Independence, edited by Shimon Shetreet and Christopher Forsyth, 187-214. Leiden: Brill.

Dicey, Albert V. 1959. Introduction to the Study of the Law of the Constitution. Basingstoke: Macmillan.

Dzehtsiarou, Kanstantsin. 2015. European Consensus and the Legitimacy of the Strasbourg Court. Cambridge: Cambridge University Press. 
Engel, Norbert P. 2012. 'More Transparency and Governmental Loyalty for Maintaining Professional Quality in the Election of Judges to the European Court of Human Rights'. Human Rights Law Journal 32(7-12):448-54.

Follesdal, Andreas. 1998. 'Survey Article: Subsidiarity'. The Journal of Political Philosophy 6(2): 190-218.

Follesdal, Andreas. 2014. 'Legitimacy Challenges and What to Do About Them: Accountability and Authority of the European Court of Human Rights'. In Proceedings of Conference on the Long-term Future of the European Court of Human Rights, edited by Council of Europe and PluriCourts, 78-85. Strasbourg: Council of Europe.

Follesdal, Andreas. 2017. 'Independent Yet Accountable: Stress Test Lessons for the European Court of Human Rights'. Maastricht Journal of European and Comparative Law 24(4): 484-510.

Fuller, Lon L. 1964. The Morality of Law. New Haven, CT: Yale University Press.

Gallie, Walter B. 1955-56. 'Essentially Contested Concepts'. Proceedings of the Aristotelian Society 56:167-98.

Gerards, Janneke. 2011. 'Pluralism, Deference and the Margin of Appreciation Doctrine'. European Law Journal 17(1):80-120.

Hurd, Ian. 2015. 'The International Rule of Law and the Domestic Analogy'. Global Constitutionalism 4(3):365-95.

Kosar, David. 2015. 'Selecting Strasbourg Judges: A Critique'. In Selecting Europe's Judges: A Critical Review of the Appointment Procedures to the European Courts, edited by Michal Bobek, 120-61. Oxford: Oxford University Press.

Kratochvil, Jan. 2011. 'The inflation of the Margin of Appreciation by the European Court of Human Rights'. Netherlands Quarterly of Human Rights 29(3):324-57.

Krygier, Martin. 2008. 'The Rule of Law: Legality, Teleology, Sociology'. In Relocating the Rule of Law, edited by Gianluigi Palombella and Neil Walker, 45-69. Oxford: Hart.

Kuijer, Martin. 1997. 'Voting Behaviour and National Bias in the European Court of Human Rights and the International Court of Justice'. Leiden Journal of International Law 10(1): 49-67.

Kumm, Mattias. 2003-04. 'International Law in National Courts: The International Rule of Law and the Limits of the Internationalist Model'. Virginia Journal of International Law 44(1): 19-32.

Kumm, Mattias. 2009. 'The Cosmopolitan Turn in Constitutionalism: On the Relationship Between Constitutionalism in and Beyond the State'. In Ruling the World? Constitutionalism, International Law, and Global Governance, edited by Jeffrey L. Dunoff and Joel P. Trachtman, 257-324. Cambridge: Cambridge University Press.

Letsas, George. 2007. A Theory of Interpretation of the European Convention on Human Rights. Oxford: Oxford University Press.

Macdonald, Ronald St. J. 1993. 'The Margin of Appreciation.' In The European System for the Protection of Human Rights, edited by Ronald St J. Macdonald and Franz Matcher, 83-124. Dordrecht: Martinus Nijhoff.

Pavel, Carmen E. 2019. 'The International Rule of Law'. Critical Review of International Social and Political Philosophy 23(3):332-51.

Pettit, Philip. 1997. Republicanism: A Theory of Freedom and Government. Oxford: Clarendon Press.

Pettit, Philip. 2009. 'Law and Liberty'. In Legal Republicanism: National and International Perspectives, edited by Samantha Besson and José Luis Martí, 39-59. Oxford: Oxford University Press. 


\section{ANDREAS FOLLESDAL}

Pettit, Philip. 2010. 'Legitimate International Institutions: A Neo-Republican Perspective'. In The Philosophy of International Law, edited by Samantha Besson and John Tasioulas, 139-60. Oxford: Oxford University Press.

Pettit, Philip. 2015. 'The Republican Law of Peoples: A Restatement'. In Domination and Global Political Justice: Conceptual, Historical, and Institutional Perspectives, edited by Barbara Buckinx, Jonathan Trejo-Mathys and Timothy Waligore, 37-70. New York: Routledge. Raz, Joseph. 1979. The Authority of Law. Oxford: Oxford University Press.

Raz, Joseph. 2019. 'The Law's Own Virtue'. Oxford Journal of Legal Studies 39(1):1-15.

Sands, Philippe, Mackenzie, Ruth and McLachlan, Campbell. 2005. 'The Burgh House Principles on the Independence of the International Judiciary'. The Law and Practice of International Courts and Tribunals 4(2):247-60.

Shapiro, Martin. 1981. Courts: A Comparative and Political Analysis. Chicago: University of Chicago Press.

Skinner, Quentin. 1998. Liberty Before Liberalism. Cambridge: Cambridge University Press.

Stone Sweet, Alec and Brunell, Thomas L. 2013. 'Trustee Courts and the Judicialization of International Regimes: The Politics of Majoritarian Activism in the European Convention on Human Rights, the European Union, and the World Trade Organization'. Journal of Law and Courts 1(1):61-88.

Tamanaha, Brian Z. 2004. On the Rule of Law: History, Politics, Theory. Cambridge: Cambridge University Press.

Tamanaha, Brian Z. 2012. “The History and Elements of the Rule of Law." Singapore Journal of Legal Studies, December:232-47.

Ulfstein, Geir. 2018. 'International Courts and Tribunals and the Rule of Law in Asia'. In Global Constitutionalism from European and East Asian Perspectives, edited by Takao Suami, Anne Peters, Dimitri Vanoverbeke and Mattias Kumm, 518-30. Cambridge: Cambridge University Press.

Voeten, Erik. 2008. 'The Impartiality of International Judges: Evidence from the European Court of Human Rights'. American Political Science Review 102(4):417-33.

Voeten, Erik. 2013. 'International Judicial Independence'. In Interdisciplinary Perspectives on International Law and International Relations: The State of the Art, edited by Jeffrey L Dunoff and Mark A Pollack, 421-45. Cambridge: Cambridge University Press.

Waldron, Jeremy. 1989. 'The Rule of Law in Contemporary Liberal Theory'. Ratio Juris 2(1): 79-96.

Waldron, Jeremy. 2002. 'Is the Rule of Law an Essentially Contested Concept (in Florida)?' Law and Philosophy 21(2):137-64.

Waldron, Jeremy. 2006. 'The Rule of International Law'. Harvard Journal of Law and Public Policy 30(1):15-30.

Waldron, Jeremy. 2011. 'Are Sovereigns Entitled to the Benefit of the International Rule of Law?' European Journal of International Law 22(2):315-43.

Waldron, Jeremy. 2016. 'The Rule of Law'. In The Stanford Encyclopedia of Philosophy, available at $<$ https://plato.stanford.edu/entries/rule-of-law $>$. 